\title{
THE ABILITY OF FINANCIAL RATIOS, INFLATION AND GROSS DOMESTIC PRODUCT (GDP) TO PREDICT THE GROWTH OF COMPANY PROFIT
}

\author{
Ika Wahyu Nurrini ${ }^{1}$ and Sukirno ${ }^{2 *}$ \\ 1,2 Universitas Negeri Yogyakarta, Indonesia
}

\begin{abstract}
This research was conducted to gather information about the influence of Current Ratio, Total Asset Turnover, Leverage Ratio, Profit Margin, Return on Asset, Inflation and Gross Domestic Product on profit growth at service companies in Indonesia Stock Exchange partially and simultaneously. The purposive sampling technique was used to collect the samples. The amount of samples in this research were the 40 service companies in the property and real estate sector listed in the Indonesia Stock Exchange in the 2014-2016 period. The classic assumption test was done before the multiple linear analysis, $t$ test, $F$ test and $R^{2}$ were used to implement the hypothesis test. The test results show only partially, the Return On Asset has a positive and significant effect to profit growth, while the variable of Current Ratio, Total Asset Turnover, Leverage Ratio, Profit Margin, Inflation and Gross Domestic Product have insignificant effects to profit growth. Simultaneously, the Current Ratio variable, Total Asset Turnover, Leverage Ratio, Profit Margin, Return On Asset, Inflation and Gross Domestic Product have significant effects to profit growth.

Keywords: Current Ratio, Gross Domestic Product, Inflation, Leverage Ratio, Profit Growth, Profit Margin, Return On Asset, and Total Asset Turnover
\end{abstract}

\section{INTRODUCTION}

As times progressed and technological competitoon between companies are tighter. For compainies to survive in the tight competition, they have to be able to compete and develop. That development will be supported with the presence of management ability in determining policies in plannig, obtaining, and using funds to maximize company values (Gunawan and Wahyuni, 2013).

According to Alam (2007:197) a service company is a company whose operational activities are producing intangible products with a purpose for obtaining profit. Today compainies in the service sector already experience significant increase. Such as in the services of real estate, property, transportation, banking, trade, insurance and investment. According to World Bank data in okezone.com (accessed on September 20 2017) there are several sectors which are the mainstay of Indonesia for maximizing economic growth, one of which is the service sector. This sector has an increasing contribution to the Indonesian economy and trade, although the portion is still under the level reached by many other middle income countries.

According to IAI in Ghozali and Chariri (2014) profit is an economic increase of one accounting period in the form of income or additional assets or liability decrease which causes an equity increase which is not from investor contribution. Profit is very useful for companies for theis survival. For investors, profit provides information whether the company performance functions well or not. Other than that profit also provides information to investors if they will

* Corresponding author. Email address: sukirno@uny.ac.id 
invest their funds and predict profit in the future. Profit that experience increase is a good word for investors, while decreasing profit is a bad word for investors (Erselina and co, 2014).

Companies desire profit for the next year to be higher than the previous year. According to Simamora (2000) as cited by Marbeya and Suaryana (2006) the profit of a company from year to year is able to experience increase or decrease. Therefore it is said that profit for the future cannot be predicted surely.

Adisetiawan (2012) as cited by Juliana and Sulardi (2003) stated that company performance is able to be seen in the financial report published by the company in every period. The goal of the financial report according to the Financial Accounting Standard Statement No.1 is to provide information that concerns financial position, performance, and financial position change of a company that is useful for most users in economic decision making. Company financial reports provide information about financial position, profit and loss, and finance position change.

For knowing and understanding financial reports to be easily understood by the company's internal and external party, a financial report analysis needs to be implemented. The ratio analysis is a technique which is able to be used for analyzing financial reports. For knowing if a company obtained profit or experience profit growth a count and interpretation of the company financial ratio can be implemented (Wicaksono, 2011). By implementing financial ratio analysis the parties of interest will know the financial condition of a company. This is the same opinion with Kamal (2007) that by using an analysis instrument in the form of this ratio, the illustration or explanation about the situation of the fianancial position of a company will be provided to analysts especially if the ratio number is compared with the comparison ratio number used as the standard.

According to Harmono (2009:106) financial ratio analysis is divided to 5 ratios which are liquidity ratio, activity ratio, solvability ratio/leverage, profitability ratio, and company value ratio. The finance ratios used in this research are the liquidity ratio, leverage ratio, activity ratio, and profitability ratio. The liquidity ratio used is the Current Ratio. The Current Ratio shows the ability of the company to pay its short term liabilities by using the current assets (Home and Wachowicz, 2005:206).

Research results of Trirahaju (2015) shows that Current Ratio has a positive influence to profit growth in garment and textile companies in the Indonesian Stock Exchange. As well as the research results of Suryadi (2009) which shows that Current ratio shows a significant influence to profit growth in manufacturing companies that are listed in the Indonesian Stock Exchange. But Julianti (2014) in her research shows that Current Ratio does not influence significantly to property and real estate company profit growth.

The activity ratio used is the Total Asset Turnover. The Total Asset Turnover shows the effectiveness of a company in managing asset rotation itself (Kasmir, 2011:133). Research results of Fadela (2015) shows that Total Asset Turnover has a significant influence to profit growth in manufacturing companies of the consumption goods sector listed in the Indonesian Stock Exchange. As well as the research implemented by Pascarina (2016) which stated that Debt to Asset Ratio has a significant influence to profit growth in manufacturing companies of the consumer goods producing raw materials listed in the Indonesian Stock Exchange. This is different from the research 
implemented by Andriyani (2015) which shows that Debt to Asset Ratio is proven to not have an influence to profit growth in mining companies listed in the Indonesian Stock Exchange.

The profitability ratios used are the Profit Margin and Return On Asset. The Profit Margin (Hanafi, 2014:42) is an analysis used for assessing how far companies are able to produce net profit in certain sales. Profit Margin is included in the profitability ratio group. The research results of Wibisono (2016) which tests the influence of financial performance to profit growth in automotive companies in the Indonesian Stock Exchange shows that Net Profit Margin has a significant influence to profit growth. The research implemented by Sulistyowati (2017) also concludes that Net Profit Margin has a positive and significant influence to profit growth in food \& beverage companies listed in the Indonesian Stock Exchange. But it is different from Safitri (2016) which in her research concludes that Net Profit Margin does not influence significantly to the profit growth of PT. Kalbe Farma Tbk.

The Return On Asset measures the company's ablility level for obtaining net profit by being based on total assets (Hanafi, 2014:42). Return On Asset is included in the profitability ratio group. Bionda and Mahdar (2017) tested the influence of gross profit margin, net profit margin, return on asset, and return on equity to profit growth in manufacturing companies in the Indonesian Stock Exchange. The research results show that Return On Asset has a positive and significant influence to profit growth. That research result is in line with the research implemented by Suryani and Habibie (2017) which concluded that Return On Asset has an influence to banking profit growth. The research implemented by Mahmudah (2015) concluded that ROA does not influence to profit growth in LQ-45 companies in the 2010-2013 period.

The macroeconomic factor is also predicted to be able to influence investor insterest to invest in companies. The macroeconomic factors are matters such as inflation and GDP. According to Boediono (2008:155) inflation is a tendency of increased prices generally and continously. Price increase from just one or two goods are not able to be called inflation except if the increase spreads (or causes price increase) in other goods. According to Fernando (2016) inflation is able to influence profit levels of companies and society purchasing power. That is because the profit level of a company is very dependent on the amount of sales done by a company. Meanwhile Gross Domestic Product is the market value of all end goods and services which are produced in a country in a certain time period (Mankiw, 2012:6).

Table 1 Indonesian Inflation and GDP Growth Rate
\begin{tabular}{ccc}
\hline Year & Inflation & GDP Growth Rate \\
\hline 2014 & $8.36 \%$ & $5.01 \%$ \\
\hline 2015 & $3.35 \%$ & $4.88 \%$ \\
\hline 2016 & $3.02 \%$ & $5.02 \%$ \\
\hline
\end{tabular}

Source: Bank Indonesia and Central Bureau of Statistics

Based on the table above the inflation from the years 2014-2016 experienced a significant decrease. In 2014 the inflation as large as 8.36\% experienced decrease so in 2015 becomes $3.35 \%$ and in 2016 experienced decrease again so it became $3.02 \%$, while GDP growth tends to be fluctuative. 
In 2014 the GDP growth is 5.01\%, while in 2015 the GDP growth decreased to $4.88 \%$ and in 2016 GDP growth experienced increase to become $5.02 \%$.

Dwijayanthy and Noami (2009) tested the influence of inflation to bank profitability, they concluded that inflation has a negative influence to bank profitability. Dwidingga (2015) stated that inflation influences profitability. It differs with the research of Setiawan and Hanryono (2016) which stated that inflation levels do not influence to foreign exchange private bank profit growth which is listed in the Indonesian Stock Exchange in the 2009-2013 period.

Research results of Trirahaju (2015) showed that GDP does not influence to profit growth in textile and garment companies in the Indonesian Stock Exchange. As well as the research implemented by Hendrayanti and Muharam (2013) concluded that economic growth does not influence significantly to banking profitability. It differs from the research result implemented by Khairunnisah (2016) which stated that GDP influences company profitability.

Based on the background above, the researcher intends to implement further research about financial ratio analysis and macroeconomic factors partially and simultaneously. The researcher limits the ratio analysis which covers Current Ratio (CR), Total Asset Turnover (TATO), Leverage Ratio, Profit Margin, Return On Asset (ROA). The macroeconomic factors used are Inflation and Gross Domestic Product (GDP). Because of that, the researcher is interested to research The Ability Of Financial Ratios, Inflation And Gross Domestic Product (GDP) To Predict The Growth Of Company Profit (A Study in Service Companies Listed in the Indonesian Stock Exchange 2014-2016 Period).

\section{RESEARCH METHOD}

The research is implemented using a quantitative research by observing data. The data used is the secondary data. Secondary data is data obtained indirectly and through intermediaries (Indriantoro and Supomo, 2002:147) This research includes ex post facto research because the research is implemented with data that is gathered after a fact occurs.

This research is implemented by obtaining financial report data of service companies which are in the Indonesian Stock Exchange in the 20142016 period. Data is obtained from the website www.idx.co.id. The Inflation data is implemented by obtaining data from the website www.bi.go.id, and the GDP data is implemented by obtaining data from www.bps.go.id. Which are implemented in the months of February 2018-March 2018.

This research uses one dependent variable and seven independent variables. The operational definitions of each variable in this research are as the following:

1. Profit Growth

Profit growth is the difference from today's period profit with the profit of the previous period then divided with the profit of the previous period. The net profit in this research which is used is the after tax net profit. Profit growth is able to be counted by using the equation (Riyanto, 2001:32) 
THE ABILITY OF FINANCIAL RATIOS, INFLATION AND GROSS DOMESTIC PRODUCT (GDP) TO PREDICT THE GROWTH OF COMPANY PROFIT

Remarks:

$$
\text { Profit Growth }=\frac{\text { Net profit }(t)-\text { Net profit }(t-1)}{\text { Net profit }(t-1)}
$$

Net profit $(\mathrm{t})$ : Net profit year $\mathrm{t}$

Net profit $(t-1)$ : Net profit of the previous year

2. Current Ratio

Current ratio is the ratio that shows the company's ability for creating sales by using the company's current assets.

3. Total Asset Turnover

$$
\mathrm{CR}=\frac{\text { current assets }}{\text { current liabilities }}
$$

Total Asset Turnover is the ratio that shows the company's ability for creating sales by using all owned assets.

4. Leverage Ratio

$$
\text { TATO }=\frac{\text { sales }}{\text { total assets }}
$$

Leverage Ratio is the ratio that shows how far the company's assets are paid by debts.

5. Profit Margin

$$
\text { LR }=\frac{\text { total debts }}{\text { total assets }}
$$

Profit Margin is the ratio that shows the company's ability to produce net profit based on sales in a certain time.

$$
\mathrm{PM}=\frac{\text { net profit after sales }}{\text { sales }}
$$

6. Return On Asset

Return On Asset is the ratio that shows the company's ability for producing net profit based on total assets

7. Inflation

ROA $=\frac{\text { net profit after tax }}{\text { total assets }}$

Inflation is a tendency of price increase generally and continously (Boediono, 2008:155). Inflation data is obtained from the Bank Indonesia official website.

8. Gross Domestic Product

Gross Domestic Product is all of the goods and services produced by all community members including foreigners in a country in a certain time period (Soebagyo, 2013:66) Gross Domestic Product Data is obtained from the official website of the Central Bureau of Statistics.

The population used in this research are 59 service companies of the property and real estate sector listed in the Indonesian Stock Exchange. The sample is obtined by using the purposive sampling method so a sample as many as 40 companies is obtained. Therefore, the total data that is used in this research amounts to 120 .

The data analysis technique used in this research is the double regression linear analysis. Before implementing the double regression linear analysis the classic assumption tests are is implemented first. The classic assumption tests implemented are the normality test, multicolinearity test, heteroscedascity test, autocorrelation test and linearity test. 
This analysis uses the profit growth dependent variable and the independent variables of the ratio influences of Current Ratio, Total Asset Turnover, Leverage Ratio, Profit Margin, Return On Asset, and Gross Domestic Product. The double regression linear equation is able to be stated as the following:

$$
\mathrm{Y}=\mathrm{a}+\mathrm{b}_{1} \mathrm{X}_{1}+\mathrm{b}_{2} \mathrm{X}_{2}+\mathrm{b}_{3} \mathrm{X}_{3}+\mathrm{b}_{4} \mathrm{X}_{4}+\mathrm{b}_{5} \mathrm{X}_{5}+\mathrm{b}_{6} \mathrm{X}_{6}+\mathrm{b}_{7} \mathrm{X}_{7}+\mathrm{e}
$$

Then the hypothesis test is implemented with the $\mathrm{t}$ statistic test, $\mathrm{F}$ statistic test, and determination coefficient. The $t$ test is implemented for testing the significance of independent variable influence to dependent variables partially. The F test is implemented for testing the significance of independent variable influence to dependent variables simultaneously. While the determination coefficient is an instrument for measuring how far is the ability of the model in clarifying dependent variable variation (Kuncoro, 2003:220).

\section{RESEARCH RESULTS AND DISCUSSION}

Table 2 Descriptive Analysis

\begin{tabular}{cccccc}
\hline & N & Min & Max & Mean & $\begin{array}{c}\text { Std. } \\
\text { Deviation }\end{array}$ \\
\hline Profit Growth & 120 & -0.933 & 64.811 & 0.884 & 6,066 \\
CR & 120 & 0.562 & 8.801 & 2.097 & 1.431 \\
TATO & 120 & 0.012 & 0.917 & 0.303 & 0.210 \\
LR & 120 & 0.054 & 0.836 & 0.432 & 0.180 \\
PM & 120 & 0.017 & 15.093 & 0.382 & 1.374 \\
ROA & 120 & 0.001 & 0.359 & 0.065 & 0.055 \\
Inflation & 120 & 0.030 & 0.084 & 0.049 & 0.024 \\
GDP & 120 & 0.049 & 0.050 & 0.050 & 0.001 \\
Valid N (listwise) & 120 & & & & \\
\hline
\end{tabular}

Source: Processed data from the Indonesian Stock Exchange, Central Bureau of Statistics and Bank Indonesia

Based on table 2 above it is known that the samples used are as many as 120. The following are the details from the descriptive statistics table above:

The profit growth variable has a minimum value as large as -0.933 , achieved by PT. Sentul City Tbk in 2014. The maximum value as large as 64.811 is reached by PT. Fortune Mate Indonesia Tbk in 2015. The average profit growth value is as large as 0.884 with a deviation standard as large as 6.066.

The Current Ratio variable has a minimum value as large as 0.562 , achieved by PT Bhuwantala Indah Permai Tbk in 2014. The maximum value as large as 8.801 is reached by PT. Greenwood Sejahtera Tbk in 2016. The average Current Ratio value is as large as 2.087 with a deviation standard as large as 1.432 .

The Total Asset Turnover variable has a minimum value as large as 0.012 , achieved by PT Greenwood Sejahtera 2016. The maximum value as large as 0.917 is reached by PT. ACset Indonusa Tbk 2014. The average Total Asset Turnover value is as large as 0.303 with a deviation standard as large as 0.210 .

The Leverage Ratio variable has a minimum value as large as 0.054 , achieved by PT Lippo Karawaci Tbk in 2015. The maximum value as large as 
0.836 is reached by PT. PP Tbk in 2014. The average Leverage Ratio value is as large as 0.432 with a deviation standard as large as 0.180 .

The Profit Margin variable has a minimum value as large as 0.017 , achieved by PT Sitara Propertindo Tbk in 2015. The maximum value as large as 15.093 is reached by PT. Greenwood Sejahtera Tbk in 2015. The average Profit Margin value is as large as 0.382 with a deviation standard as large as 1.374 .

The Return On Asset variable has a minimum value as large as 0.001 , achieved by PT Gading Development Tbk in 2016. The maximum value as large as 0.539 is reached by PT. Fortune Matte Indonesia Tbk in 2016. The average Return On Asset value is as large as 0.065 with a deviation standard as large as 0.055 .

The Inflation variable has a minimum value as large as 0.030 in 2016 and a maximum value as large as 0.084 in 2014 . The average inflation value is as large as 0.049 with a deviation standard as large as 0.025 .

The Gross Domestic Product variable has a minimum value as large as 0.049 in 2015 and a maximum value as large as 0.050 in 2016. The average Gross Domestic Product value is as large as 0.050 with a deviation standard as large as 0.001 .

Table 3 Double Regression Linear Test Results

\begin{tabular}{cccc}
\hline Model & $\begin{array}{c}\text { Unstandardized } \\
\text { Coefficients }\end{array}$ & $\mathbf{t}$ & Sig. \\
\cline { 2 - 3 } $\mathbf{B}$ & 47.977 & 1.081 & 0.282 \\
\hline 1 (Constant) & 0.057 & 0.139 & 0.890 \\
\hline CR & 0.336 & 0.096 & 0.924 \\
\hline TATO & -1.359 & -0.309 & 0.758 \\
\hline LR & -0.091 & -0.218 & 0.827 \\
\hline PM & 41.686 & 3.861 & 0.000 \\
\hline ROA & -5.986 & -0.254 & 0.800 \\
\hline INFLATION & -988.287 & -1.098 & 0.275 \\
\hline GDP &
\end{tabular}

Source: Processed data from the Indonesian Stock Exchange, Central Bureau of Statistics and Bank Indonesia

Based on the table above the double regression linear equation is as the following:

$\mathrm{Y}=47.977+0.057 \mathrm{CR}+0.336 \mathrm{TATO}-1.359 \mathrm{LR}-0.091 \mathrm{PM}+41.686 \mathrm{ROA}-$ 5.986Inflation - 988.287GDP

Based on the equation above it is known that the constant as laege as 47.977 shows that if there are no variables of CR, TATO, LR, PM, ROA, Inflation and GDP, the profit growth will be as large as 47.977. The CR coefficient as large as 0.057 shows that in every addition of a unit it will increase profit growth as large as 0.057 . The TATO coefficient as large as 0.336 shows that for every increase of one unit the profit growth will increase as large as 0.336 . The LR coefficient as large as -1.359 shows that for every increase of one unit the profit growth will decrease as large as 1.359. The PM coefficient as large as -0.091 shows that for every increase of one unit the profit growth will decrease as large as 0.091 . The ROA coefficient as large as 41.686 shows that for every increase of one unit the profit growth will increase as large as 
41.686. The Inflation coefficient as large as $\mathbf{- 5 . 9 8 6}$ shows that for every increase of one unit the profit growth will decrease as large as 5.986. The GDP coefficient as large as -988.287 shows that for every increase of one unit the profit growth will decrease as large as 988.287.

Then for the partial hypothesis test the $t$ test is implemented. It is known that the freedom degree is (df) $=\mathrm{n}-\mathrm{k}-1=120-7-1=112$ and the trust degree as large as $5 \%$ so the t table value is obtained as large as 1.657. Based on table 3 above the following results are obtained:

The Current Ratio variable has a t count as large as 0.139 , this $t$ count value is smaller than the $t$ table which is as large as 1.657 and in the significance level of $0.890>0.050$ so it is concluded that Current Ratio does not influence significantly to profit growth in service companies in the Indonesian Stock Exchange.

The Total Asset Turnover variable has a t count as large as 0.096, this $t$ count value is smaller than the t table which is as large as 1.657 and in the significance level of $0.924>0.050$ so it is concluded that Total Asset Turnover does not influence significantly to profit growth in service companies in the Indonesian Stock Exchange.

The Leverage Ratio variable has a t count as large as -0.309 , this t count value is smaller than the table which is as large as 1.657 and in the significance level of $0.758>0.050$ so it is concluded that Leverage Ratio does not influence significantly to profit growth in service companies in the Indonesian Stock Exchange.

The Profit Margin variable has a $t$ count as large as -0.218 , this $t$ count value is smaller than the $t$ table which is as large as 1.657 and in the significance level of $0.827>0.050$ so it is concluded that Profit Margin does not influence significantly to profit growth in service companies in the Indonesian Stock Exchange.

The Return On Asset variable has a t count as large as 3.861, this t count value is larger than the $t$ table which is as large as 1.657 and in the significance level of $0.000>0.050$ so it is concluded that Return On Asset influences significantly to profit growth in service companies in the Indonesian Stock Exchange.

The Inflation variable has a $t$ count as large as -0.254 , this $t$ count value is smaller than the t table which is as large as 1.657 and in the significance level of $0.800>0.050$ so it is concluded that Inflation does not influence significantly to profit growth in service companies in the Indonesian Stock Exchange.

The Gross Domestic Product variable has a t count as large as -1.098, this t count value is smaller than the $t$ table which is as large as 1.657 and in the significance level of $0.800>0.050$ so it is concluded that Inflation does not influence significantly to profit growth in service companies in the Indonesian Stock Exchange.

Table 4 F Statistic Test Results

\begin{tabular}{lcc}
\hline \multicolumn{1}{c}{ Model } & F & Sig. \\
\hline Regression & 3.141 & 0.005 \\
\hline Residual & & \\
\hline Total & & \\
\hline
\end{tabular}

Source: Processed data from the Indonesian Stock Exchange, Central Bureau of Statistics and Bank Indonesia 
It is known the freedom degree $1(\mathrm{df} 1)=\mathrm{k}-1=7-1=6$ and freedom degree $2(\mathrm{df} 2)=\mathrm{n}-\mathrm{k}-1=120-7-1=112$, and the trust degree as large as $5 \%$ so the $\mathrm{F}$ table value is as large as 2.181 . Based on table 4 above it is known that the $\mathrm{F}_{\text {count }}$ is as large as 3.141 the $\mathrm{F}_{\text {count }}$ value is larger than the $\mathrm{F}_{\text {table }}$ which is as large as 2.181 and in the significance level of $0.005<0.050$, so it is concluded that Current Ratio, Total Asset Turnover, Leverage Ratio, Profit Margin, Return On Asset, Inflation and Gross Domestic Product simultaneously influence significantly to profit growth in service companies in the Indonesian Stock Exchange.

\begin{tabular}{cccc}
\multicolumn{3}{c}{ Table 5 Determination Coefficient Test Results } \\
\cline { 2 - 4 } Model & $\mathrm{R}$ & $\begin{array}{c}\mathrm{R} \\
\text { Square }\end{array}$ & $\begin{array}{c}\text { Adjusted } \\
\text { R Square }\end{array}$ \\
\hline 1 & 0.405 & 0.164 & 0.112 \\
\hline
\end{tabular}

Source: Processed data from the Indonesian Stock Exchange, Central Bureau of Statistics and Bank Indonesia

Based on table 5 above it is known that the determination coefficient seen in the Adjusted R Square value is as large as 0.112 or $11.2 \%$. This means that $11.2 \%$ of the profit growth variable variation is explained by the variables of Current Ratio, Total Asset Turnover, Leverage Ratio, Profit Margin, Return On Asset, Inflation and Gross Domestic Product. The other $88 \%$ is explained by other factors not studied in this research.

\section{DISCUSSION}

\section{Influence of Current Ratio to Profit Growth}

Based on partial research results Current Ratio does not influence significantly to profit growth. In other words, change of Current Ratio is followed by an increase or decrease of profit growth. This is able to be seen from regression analysis results which show that the $t$ count value as large as 0.139 is smaller than the t table which is as large as1.657 in the trust degree of 0.050 with $\mathrm{df}=112$, with a significance value of 0.890 . This significance value is larger than 0.05 so it is concluded that Current Ratio does not influence significantly to profit growth in service companies in the Indonesian Stock Exchange. Therefore, the hypothesis that states that Current Ratio has a positive influence to profit growth in service companies in the Indonesian Stock Exchange is not accepted.

Results of this research support research results implemented by Julianti (2014), Adha and Sulasmiyati (2017), and Nugroho and co (2017) which states that Current Ratio does not influence significantly to profit growth. Yet this research result does not support the research results implemented by Trirahaju (2015) and Suryadi (2009) which stated that Current Ratio has a significant influence to profit growth. As well as the research implemented by Kurniawati (2017) which states that Current Ratio has a positive and significant influence to profit change.

\section{Influence of Total Asset Turnover to Profit Growth}

Based on partial research results Total Asset Turnover does not influence significantly to profit growth. In other words, change of Total Asset 
Turnover is followed by an increase or decrease of profit growth. This is able to be seen from regression analysis results which show that the $t$ count value as large as 0.096 is smaller than the t table which is as large as 1.657 in the trust degree of 0.050 with $\mathrm{df}=112$, with a significance value of 0.924 . This significance value is larger than 0.050 so it is concluded that Total Asset Turnover does not influence significantly to profit growth in service companies in the Indonesian Stock Exchange. Therefore, the hypothesis that states that Total Asset Turnover has a positive influence to profit growth in service companies in the Indonesian Stock Exchange is not accepted.

Results of this research support research results implemented by Adha and Sulasmiyati (2017), Suryadi (2009), and Gautama and Hapsari (2016) which states that Total Asset Turnover does not influence significantly to profit growth. Yet this research result does not support the research results implemented by Fadela (2015), Sulistyowati (2017) and Hamidu (2013) which stated that Total Asset Turnover has a significant influence to profit growth.

\section{Influence of Leverage Ratio to Profit Growth}

Based on partial research results Leverage Ratio does not influence to profit growth. In other words, change of Leverage Ratio is followed by an increase or decrease of profit growth. This is able to be seen from regression analysis results which show that the t count value as large as -0.309 is smaller than the $\mathrm{t}$ table which is as large as 1.657 in the trust degree of 0.050 with $\mathrm{df}=$ 112 , with a significance value of 0.758 . This significance value is larger than 0.050 so it is concluded that Leverage Ratio does not influence significantly to profit growth in service companies in the Indonesian Stock Exchange. Therefore, the hypothesis that states that Leverage Ratio has a positive influence to profit growth in service companies in the Indonesian Stock Exchange is not accepted.

Results of this research support research results implemented by Adriyani (2015), Permatasari (2016), and Wahyuni and Gunawan (2015) which states that Debt to Asset ratio does not influence to profit growth. Yet this research result does not support the research results implemented by Wibisono (2016), Pascarina (2016) and Saputri (2017) which stated that Debt to Asset Ratio has a significant influence to profit growth.

\section{Influence of Profit Margin to Profit Growth}

Based on partial research results Profit Margin does not influence to profit growth. In other words, change of Profit Margin is followed by an increase or decrease of profit growth. This is able to be seen from regression analysis results which show that the t count value as large as -0.218 is smaller than the $\mathrm{t}$ table which is as large as 1.657 in the trust degree of 0.050 with $\mathrm{df}=$ 112 , with a significance value of 0.827 . This significance value is larger than 0.050 so it is concluded that Profit Margin does not influence significantly to profit growth in service companies in the Indonesian Stock Exchange. Therefore, the hypothesis that states that Profit Margin has a positive influence to profit growth in service companies in the Indonesian Stock Exchange is not accepted.

Results of this research support research results implemented by Safitri (2017), Siregar and Batubara (2017), and Rachmawati and Handayani (2014) which states that Net Profit Margin does not influence significantly to profit 
growth. Yet this research result does not support the research results implemented by Wibisono (2016), Sulistyowati (2017) and Saputri (2017) which stated that Net Profit Margin has a significant influence to profit growth.

\section{Influence of Return On Asset to Profit Growth}

Based on partial research results Return On Asset has an influence to profit growth. In other words, change of Return On Asset is followed by an increase or decrease of profit growth. This is able to be seen from regression analysis results which show that the t count value as large as 3.861 is larger than the $t$ table which is as large as 1.657 in the trust degree of 0.050 with $\mathrm{df}=112$, with a significance value of 0.000 . This significance value is smaller than 0.050 so it is concluded that Return On Asset does influence positivetly to profit growth in service companies in the Indonesian Stock Exchange. Therefore, the hypothesis that states that Return On Asset has a positive influence to profit growth in service companies in the Indonesian Stock Exchange is accepted.

A high Return On Asset shows the efficiency level of company asset use for producing company profit. The more efficient the company, it means that the better the company performance in producing company profit. So it will be a positive signal for investors to invest their capital because the return level of investment is large.

Results of this research support research results implemented by Andriyani (2015) and Suryani and Habibie (2017), which states that Return On Asset influences significantly to profit growth. As well as the research results implemented by Bionda and Mahdar (2017) which states that Return On Asset has a significant influence to profit growth. Yet this research result does not support the research results implemented by Ertanto (2011), Mahmudah (2015) and Permatasari (2016) which stated that Return On Asset does not influence to profit growth.

\section{Influence of Inflation to Profit Growth}

Based on partial research results inflation does not influence to profit growth. In other words, change of inflation is not followed by an increase or decrease of profit growth. This is able to be seen from regression analysis results which show that the t count value as large as -0.254 is smaller than the table which is as large as 1.657 in the trust degree of 0.050 with $\mathrm{df}=112$, with a significance value of 0.800 . This significance value is larger than 0.050 so it is concluded that inflation does not influence significantly to profit growth in service companies in the Indonesian Stock Exchange. Therefore, the hypothesis that states that inflation has a positive influence to profit growth in service companies in the Indonesian Stock Exchange is not accepted.

Results of this research support research results implemented by Setiawan and Hanryono (2016), Bhuta and Hasan (2013) which states that inflation does not influence to profit growth. As well as the research of Aditya and co. (2016) which states that inflation does not influence company profitability. Yet this research result does not support the research results implemented by Amro (2015), Gufron (2015) and Dwidingga (2015) which stated that inflation has an influence to profitability. 


\section{Influence of Gross Domestic Product to Profit Growth}

Based on partial research results Gross Domestic Product does not influence to profit growth. In other words, change of Gross Domestic Product is not followed by an increase or decrease of profit growth. This is able to be seen from regression analysis results which show that the $t$ count value as large as -1.098 is smaller than the t table which is as large as 1.657 in the trust degree of 0.050 with $\mathrm{df}=112$, with a significance value of 0.275 . This significance value is larger than 0.050 so it is concluded that Gross Domestic Product does not influence significantly to profit growth in service companies in the Indonesian Stock Exchange. Therefore, the hypothesis that states that Gross Domestic Product has a positive influence to profit growth in service companies in the Indonesian Stock Exchange is not accepted.

Results of this research support research results implemented by Trirahaju (2015), Hendrayanti and Muharam (2013) which states that Gross Domestic Product does not influence significantly to profit growth. As well as the research of Sistiyarini and Supriyono (2016) which states that Gross Domestic Product does not influence company profitability. As well as the research results implemented by Ruspandi and Asma (2014) and Khairunisah (2016) which states that Gross Domestic Product has an influence to profitability.

\section{Influence of Current Ratio, Total Asset Turnover, Leverage Ratio, Profit Margin, Return On Asset, Inflation and Gross Domestic Product simultaneously to Profit Growth}

Based on simultaneous research results, Current Ratio, Total Asset Turnover, Leverage Ratio, Profit Margin, Return On Asset, Inflation and Gross Domestic Product have influences to profit growth. In other words, if the increase of Current Ratio, Total Asset Turnover, Leverage Ratio, Profit Margin, Return On Asset, Inflation and Gross Domestic Product occurs, it will increase profit growth, Otherwise if a decrease of Current Ratio, Total Asset Turnover, Leverage Ratio, Profit Margin, Return On Asset, Inflation and Gross Domestic Product occurs. It will decrease profit growth. This is able to be observed from regression analysis results which show the $F$ count value of 3.141 which is larger than the $F$ table as large as 2.181 in the trust degree of 0.05 with df $1=6$ and $\mathrm{df} 2=112$, with a significance level of 0.005 . This significance value is smaller than 0.050 so it is concluded that Current Ratio, Total Asset Turnover, Leverage Ratio, Profit Margin, Return On Asset, Inflation and Gross Domestic Product have influences to profit growth in service companies in the Indonesian Stock Exchange. Therefore the hypothesis which states that Current Ratio, Total Asset Turnover, Leverage Ratio, Profit Margin, Return On Asset, Inflation and Gross Domestic Product simultaneously have influences to profit growth in service companies in the Indonesian Stock Exchange is accepted.

The acceptance of this hypothesis provides information that internal and external factors are able to influence company profit growth. Companies are able to use ratio analysis Current Ratio, Total Asset Turnover, Leverage Ratio, Profit Margin, Return On Asset, Inflation and Gross Domestic Product in decision making for implementing their operational activities so the acquisition of profit will increase. A good financial condition will be a good signal for investors. Therefore, investors will be interested for investing because of the large income from returns. 


\section{CONCLUSION AND SUGGESTIONS}

\section{Conclusion}

1. Based on research results the variables of Current Ratio, Total Asset Turnover, Leverage Ratio, Profit Margin, Return On Asset, Inflation and Gross Domestic Product which are predicted to influence profit growth, show only the Return On Asset variable which has a positive and significant influence to profit growth in service companies in the Indonesia Stock Exchange. Other variables which are Current Ratio, Total Asset Turnover, Leverage Ratio, Profit Margin, Inflation and Gross Domestic Product does not influence significantly to profit growth in service companies in the Indonesia Stock Exchange.

2. Based on the $t$ test by observing significance levels, the most significant variable which influence profit growth of service companies in the Indonesia Stock Exchange is the Return On Asset with a significance level as large as 0.000 . The least influential variable to profit growth in service companies in the Indonesia Stock Exchange is the Total Asset Turnover with a significance level as large as 0.924 .

3. Based on the $\mathrm{F}$ test result, it is proven that the $\mathrm{F}$ significance as large as 0.005 is smaller than 0.050. Therefore, the independent variables in the research which consist of Current Ratio, Total Asset Turnover, Leverage Ratio, Profit Margin, Return On Asset, Inflation and Gross Domestic Product which simultaneously influence significantly to profit growth in service companies in the Indonesian Stock Exchange.

4. Based on the Adjuster R Square value all independent variables in this research are only able to provide $11.2 \%$ from all independent variables. The other $88.8 \%$ are explained by other factors which are not yet studied in this research which influence profit growth.

\section{Suggestions}

Companies are able to consider the Return On Asset factor which influence profit growth. It is expected that by considering that factor, companies are able to make decisions for solving obstacles which might occur, so the profit obtained by companies will be larger. Other than that companies are expected for observing more of other factors which are not researched which are able to influence profit growth.

For investors, before implementing investment, they should pay attention to the Return On Asset factor which influences profit growth. Therefore, investors will know the return accepted of the implemented investment.

For further researchers, it is expected to be able to use other variables other than in this research which are predicted to be able to influence profit growth. Other than that, further researchers are expected to be more detailed in observing data in the financial reports of each company every year which are able to be research samples and consider relevant facts, to be able to reduce bias risks. 
AFEBI Accounting Review (AAR)

Vol.03 No.01, June 2018

\section{References}

Adisetiawan. R. (2012). Analisis Pengaruh Kinerja Keuangan Dalam Memperediksi Pertumbuhan Laba. Jurnal Aplikasi Manajemen, Vol.10, No.3.

Afrianto, D. (22 Maret 2017).Sektor Jasa Bisa Jadi Andalan Pertumbuhan Ekonomi Indonesia. Okezonefinance. Accessed on September 202017 from https://economy.okezone.com/read/2017/03/22/20/1649025/sektorjasa-bisa-jadi-andalan-pertumbuhan-ekonomi-indonesia.

Alam, S. (2007). Ekonomi Untuk SMA dan MA Kelas XI. Jakarta: Esis Erlangga.

Boediono. (2008). Seri Sinopsis pengantar Ilmu Ekonomi No. 2 Ekonomi Makro. Yogyakarta: BPFE.

Indonesian Stock Exchange .Accessed on January 182018 from http://www.idx.co.id.

Inflation data. Accessed On November 272018 from http://www.bi.go.id.

GDP Growth Data Rate. Accessed on November 272017 from https://www.bps.go.id.

Erselina, A., Sari, R.N., \& A Azhar, A. (2014). Analisis Prediksian Rasio Keuangan Terhadap Perubahan Laba Pada Perusahaan Property dan Real Estate yang Terdaftar Di Bursa Efek Indonesia (BEI) Tahun 20082011.JOM FEKON, Vol.1, No.2.

Fernando, F. (2016). Analisis Rasio Keuangan, Ukuran Perusahaan, Tingkat Inflasi, dan Arus Kas Bebas Serta Pengaruhnya Terhadap Pertumbuhan Laba Perusahaan. Jurnal Elektronik Tugas Akhir Mahasiswa, Universitas Maritim Raja Ali Haji.

Ghozali, I., \& Chariri, A. (2014). Teori Akuntansi. Semarang: Badan Penerbit Universitas Diponegoro.

Gunawan, A., \&Wahyuni, S.F. (2013). Pengaruh Rasio Keuangan Terhadap Pertumbuhan Laba Pada Perusahaan Perdagangan di Indonesia. Jurnal Manajemen \& Bisnis, Vol.13, No.01.

Hanafi, M.M. (2014). Manajemen Keuangan, Edisi Pertama. Yogyakarta: BPFE.

Harmono. (2009). Manajemen Keuangan Berbasis Balance Scorecard (Pendekatan Teori, Kasus, dan Riset Bisnis). Jakarta: Bumi Aksara.

Horne, J.V., \& Wachowicz, J.M. (2005). Prinsip-Prinsip Manajemen Keuangan. Jakarta: Salemba Empat.

Indriantoro, N \& Supomo, B. (2002). Metodologi Penelitian Bisnis Untuk Akuntansi dan Manajemen. Yogyakarta: BPFE. 
Kamal. A. (2007). Manfaat Analisis Rasio Keuangan Untuk Menilai Kinerja Keuangan Perusahaan. Theisis. Universitas Widyatama.

Kasmir. (2011). Analisis Laporan Keuangan. Jakarta: Rajagrafindo Persada.

Kuncoro, M. (2003). Metode Riset untuk Bisnis dan Ekonomi. Jakarta: Erlangga.

Machfoedz, M. (1996). Akuntansi Manajemen Perencanan dan Pembuatan Keputusan Jangka Pendek. Yogyakarta: STIE Widya Wiwaha.

Mankiw, N.G., Quah, E., \& Wilson, P. (2012). Pengantar Ekonomi Makro. Jakarta: Salemba Empat.

Marberya, N.P.E., \& Suaryana, A. (2006). Pengaruh Pemoderasi Pertumbuhan Laba terhadap Hubungan antara Ukuran Perusahaan, Debt to Equity Ratio dengan Profitabilitas pada Perusahaan Perbankan yang Terdaftar di PT. Bursa Efek Jakarta. Jurnal Ilmiah Akuntansi dan Bisnis.

Riyanto, B. (2001). Dasar-Dasar Pembelajaran Perusahaan, Edisi Keempat, Cetakan Ketujuh. Yogyakarta: BPFE.

Soebagyo, D. (2013). Perekonomian Indonesia. Surakarta: Muhamadiyah University Surakarta.

Wicaksono, V. (2011). Analisis Rasio Keuangan Dalam Memprediksi Perubahan Laba: Suatu Studi Empiris pada Perusahaan Manufaktur Yang Terdaftar Pada Bursa Efek Indonesia (Periode Tahun 2006-2009). Thesis, Universitas Diponegoro. 